\title{
KEPEMIMPINAN KEPALA MADRASAH DALAM MENINGKATKAN \\ MUTU PENDIDIKAN DI MADRASAH TSANAWIYAH SATU ATAP \\ MIKRAJUSSIBYAN NW SELANGLET DESA PENUJAK KECAMATAN \\ PRAYA BARAT KABUPATEN LOMBOK TENGAH
}

\author{
Azhar \\ aaz.zhar1945@gmail.com \\ Dosen IAI Hamzanwadi Anjani
}

\begin{abstract}
This Research was done with the purpose to describe, express, and explain two things those are vision, mission of Junior High School of Satu Atap Mikrajussibyan NW Selanglet and the strategy of Headmaster to Increase quality of education in Junior High School of SatuAtapMikrajussibyan NW Selanglet. Method that used in this collecting data cover; interview, observation, and documentation. The data that has been collected through those techniques was organized, interpreted, and analyzed repeatedly according with the approachment used to arrange concept and abstraction of research finding. Credibility of the data checked with the procedure of triangulation, member checking, and discussion of coleage, whereas dependability and compermability was did by guidance as dependent auditor. Output (Result) of this research showed that the headmaster of Junior High School of Satu Atap Mikrajussibyan NW Selanglet implementated vision and his mission with the supporting of all school component in order to cooperated to create vision and mission of the school. Headmaster's way to support all component were : giving instruction to all components having superior and Islamic cultures, making vision and mission of school as an instrument to give direction and aim of school, bring into reality national education standard, understand about vison and mission, make vision and mission of school as a translation to make it real vision of school, Effort in order to make mission of school in line with the development of technology and information, make mission as a booster to excavate potential, creation, and innovation from the citizen of school in order to make vision into reality.
\end{abstract}

Keyword : Leadership, Headmaster, And Quality Of Education 


\begin{abstract}
ABSTRAK
Penelitian ini dilakukan dengan tujuan menggambarkan, mengungkapkan dan menjelaskan dua hal yaitu Implementasi visi, misi, Madrasah Tsanawiyah Satu Atap Mikrajussibyan NW Selanglet dan strategi kepala madrasah dalam meningkatkan mutu pendidikan di Madrasah Tsanawiyah Satu Atap Mikrajussibyan NW Selanglet. Adapun Metode pengumpulan data yang digunakan dalam penelitian ini meliputi; wawancara, observasi, dokumentasi. Data yang terkumpul melalui teknik tersebut diorganisasi, ditafsirkan, dan dianalisis secara berulang-ulang sesuai dengan pendekatan yang digunakan guna menyusun konsep dan abstraksi temuan penelitian. Kredibilitas data dicek dengan prosedur triangulasi, pengecekan anggota, dan diskusi teman sejawat sedangkan kebergantungan (dependability) dan kepastian (compermability) dilakukan oleh para pembimbing sebagai dependent auditor. Hasil penelitian ini menunjukkan bahwa Kepala Madrasah Tsanawiyahh Satu Atap Mikrajussibyan NW Selanglet, mengimplementasikan visi misinya dengan mendorong segenap komponen madrasah untuk bekerjasama mewujudkan visi misi madrasah. Adapun cara Kepala Madrasah mendorong segenap komponennya adalah, dengan mengarahkan semua komponen untuk memiliki budaya-budaya unggul dan islami, menjadikan visi madrasah sebagai alat untuk mengarahkan haluan dan tujuan madrasah, mewujudkan standar nasional pendidikan, memahami dan menjiwai visi misi madrasah, menjadikan misi madrasah sebagai penjabaran visi untuk mewujudkan tujuan madrasah, Mengupayakan agar misi Madrasah tetap sejalan dengan perkembangan teknologi dan informasi, menjadikan misi sebagai pendorong untuk menggali potensi, kreasi, dan inovasi yang dimiliki warga Madrasah demi terwujudnya tujuan.
\end{abstract}

Kata kunci : Kepemimpinan, Kepala Madrasah, Dan Mutu Pendidikan.

\title{
PENDAHULUAN
}

Dalam realitas sejarah, madrasah tumbuh dan berkembang dari, oleh dan untuk masyarakat Islam. Sehingga sejak awal, madrasah merupakan konsep pendidikan berbasis masyarakat (community based education). Masyarakat sebagai individu maupun organisasi dengan didorong semangat keagamaan atau dakwah, membangun madrasah untuk memenuhi kebutuhan pendidikan anakanak mereka, ini dapat dilihat dari prosentase kepemilikan madrasah di Indonesia yang tercatat $90 \%$ milik swasta dan sisanya berstatus negeri, dan ini berbanding terbalik dengan sekolah-sekolah umum. ${ }^{1}$

${ }^{1}$ Muhaimin, Pengembangan Kurikulum Pendidikan Agama Islam (Jakarta: Raja Grafindo Persada, 2005),184-185. 
Hingga hari ini, sebagaimana lembaga pendidikan pada umumnya, madrasah masih dihadapkan pada sejumlah persoalan klasik seperti kelemahan infrastruktur, sumber daya pendidik dan tenaga kependidikan, kualitas calon siswa, kurikulum, proses pembelajaran, dan manajemen kelembagaan. Masalah tersebut sebenarnya dilatarbelakangi oleh kondisi awal yang melibatkan banyak aspek.2

Tingginya peran masyarakat dalam memberdayakan madrasah ternyata belum dapat meningkatkan mutu pendidikan madrasah secara signifikan. Persepsi miring atas madrasah sebagai lembaga pendidikan "kelas dua" belum dapat dijawab secara tuntas oleh para pengelola madrasah. Bahkan, di beberapa sisi, madrasah masih tampak sebagai "cagar budaya" untuk mempertahankan fahamfaham keagamaan tertentu. Belum menumbuhkan mobilitas antar generasi, sehingga masih belum tampak perannya sebagai pendidikan yang menjanjikan masa depan.3

Realita ini berbanding terbalik dengan tuntutan akan pendidikan bermutu yang semakin hari semakin kuat.4Tingginya tuntutan akan pendidikan yang bermutu sudah seyogyanya direspon oleh para pengelola madrasah dengan sikap yang rasional dan lebih berorientasi pada kebutuhan masyarakat secara luas. Respon tersebut diejawantahkan dalam bentuk strategi peningkatan mutu pendidikan yang selanjutnya diupayakan implementasinya secara bertahap.

Evaluasi tersebut berdampak besar pada diri seorang hamba. Ia akan sadar bahwa telah banyak maksiat yang ia perbuat, dan ampunan Allah belum tentu ia terima. Sedangkan amal saleh yang ia kerjakan terlalu sedikit. Sehingga dengan

\footnotetext{
${ }^{2}$ Rohmat Mulyana, “Quo Vadis Madrasah”, www. Pikiran-Rakyat. Com (diakses pada 22
} November 2015).

${ }^{3}$ A. Malik Fajar, Visi Pembaruan Pendidikan Islam (Jakarta: LP3NI, 1998), 6; Lihat juga Muhaimin, Paradigma Pendidikan Islam:Upaya Mengefektifkan Pendidikan Agama Islam di Sekolah (Bandung: Remaja Rosdakarya, 2004), 32.

${ }^{4}$ Ada dua faktor yang menuntut setiap lembaga pendidikan untuk secara terus menerus meningkatkan kualitas pendidikan, yaitu faktor tantangan era globalisasi dan factor kesadaran orang tua akan pendidikan yang bermutu. Baca Madyo Ekosusilo, Sekolah Unggul Berbasis Nilai: Studi Multikasus di SMA Negeri 1, SMA Regina Pacis, dan SMA Al Islam 1 Surakarta (Sukoharjo: Bantara Press, 2003), 1. 
mengevaluasi (muhaasabah) diri, seseorang akan menambah perbuatan baiknya dan akan berhenti melakukan perbuatan yang buruk 5

Dalam hal ini, dalam kontek pendidikan yang harus di evaluasi dan yang menjadi tantangan adalah mutu pendidikan yang telah menjadi kebutuhan masyarakat yang semakin tinggi yang menuntut perubahan-perubahan pada lembaga pendidikan Islam. Untuk itu, sudah sewajarnya apabila kemudian para pengelola madrasah berupaya untuk berkaca dan mengevaluasi diri dari beberapa madrasah atau sekolah favorit yang dapat mengelola lembaganya secara mandiri dan profesional sesuai dengan kebutuhan masyarakat sebagai pelanggan jasa pendidikannya.

Madrasah-madrasah atau Sekolah-Sekolah favorit yang mayoritas berbasis masyarakat menengah ke atas tersebut memberi banyak inspirasi pada lembaga lembaga pendidikan Islam. Para pengelola lembaga pendidikan Islam pun menyadari bahwa lembaga pendidikan Islam perlu dikelola lebih kreatif, inovatif dan dinamis seiring dengan perubahan masyarakat yang semakin cepat dan terbuka. Pengelola lembaga pendidikan Islam yang sekedar bergaya menunggu dan terlalu berpegang pada aturan-aturan birokratis atau berfikir secara structural dan tidak berani melakukan inovasi untuk menyesuaikan tuntutan masyarakat, akan ditinggalkan oleh peminatnya. Pengelola lembaga pendidikan Islam memaklumi bahwa pada masyarakat yang berkembang demikian cepat yang di dalamnya terjadi kompetisi secara terbuka, selalu dituntut mutu pelayanan yang berbeda dengan masyarakat sebelumnya. 6

Rupanya hal ini kemudian ditindaklanjuti secara baik oleh beberapa pengelola madrasah dan lembaga pendidikan Islam lainnya. Setidaknya, dalam dua dekade terakhir telah bermunculan beberapa lembaga pendidikan Islam yang berupaya menampilkan wajah baru7 lembaga pendidikan Islam menjadi lebih

\footnotetext{
${ }^{5}$ Ibid.

${ }^{6}$ Imam Suprayogo, Pendidikan Berparadigma Al Qur'an (Malang: Aditya Media bekerjasama dengan UIN Malang Press, 2004), 212; Lihat juga, Syafaruddin, Manajemen Mutu Terpadu dalam Pendidikan: Konsep, Strategi dan Aplikasi (Jakarta: Grasindo, 2002), 20. Logos, t.t).

Azra, Azyumardi, Pendidikan Islam; Tradisi dan Modernisasi Menuju Milenium Baru, (Jakarta:
} 
adaptif dan responsif. Seperti Madrasah Model, Sekolah Islam Terpadu, juga seperti Madrasah Tsanawiyah Satu Atap Mikrajussibyan NW Selanglet, Lembaga-lembaga pendidikan tersebut berusaha menampilkan pendidikan Islam sebagai lembaga pendidikan yang bermutu dan modern dari berbagai jenis dan jenjang.8 Bersamaan dengan kemunculan beberapa sekolah Islam tersebut Kementerian Agama juga berupaya untuk menampilkan konsep madrasah bermutu dengan beberapa kebijakan yang menunjuk beberapa madrasah tertentu sebagai madrasah unggulan dan percontohan atau yang juga dikenal dengan Madrasah Model.

Semarak pembaruan lembaga pendidikan Islam ini banyak diikuti oleh beberapa madrasah Swasta dan sekolah Islam dibebrapa daerah. Beberapa madrasah yang tadinya tampak biasa-biasa saja berupaya berbenah untuk meningkatkan mutu pendidikannya.di Lombok tengah misalnya, muncul beberapa madrasah dan sekolah Islam dari tingkat dasar hingga lanjutan atas yang banyak diminati masyarakat karena prestasi mutu pendidikannya.

Meski secara umum masih menjadikan masyarakat perkotaan sebagai basis pelanggannya, beberapa madrasah swasta tetap berkembang cukup pesat dan kian banyak bermunculan. Kota-kota besar tampaknya masih menjadi sentral lembaga lembaga pendidikan tersebut. Di Lombok tengah misalnya, untuk tingkat sekolah lanjutan pertama telah muncul berapa madrasah Tsanawiyah yang memiliki peminat jauh melampaui kapasitas madrasah. Sebut saja, Madrasah Tsanawiyah Satu Atap. Mikrajussibyan NW Selanglet yang dikelola oleh Yayasan Pondok Pesanteren Mikrajussibyan NW Selanglet, yang merupakan salah satu madrasah yang mendapatkan bantuan dari kemitraan Australia yang meperoleh nilai akreditasi A. Dan telah banyak memperoleh prestasi serta termasuk salah satu pemegang sertifikat madrasah terbaik di Nusa Tenggara Barat. Oleh karenanya, layak disebut sebagai sekolah atau madrasah unggul. Ciri-ciri

\footnotetext{
${ }^{8}$ Tesis Jones (1989) yang menyatakan bahwa kebutuhan dan harapan masyarakat akan mutu pelayanan pendidikan yang baik menjadi faktor pemicu utama inovasi manajemen pendidikan, terbukti di sini. Lihat Sudarman Danim, Visi Baru Manajemen Sekolah: Dari Unit Brokrasi ke Lembaga Akademik (Jakarta: Bumi Aksara, 2007), 61.
} 
keunggulan sekolah seperti prestasi akademik dan non-akademik yang di atas rata-rata, sarana dan prasarana dan layanan lebih lengkap,sistem pembelajaran lebih baik dan waktu belajar lebih panjang,selektif dalam menerima siswa, mendapat animo yang besar dari masyarakat, dan sebagainya telah mereka penuhi dengan baik.

Menurut Mulyasa mengatakan bahwa pendidikan dapat memberikan kontribusi yang sangat besar terhadap kemajuan suatu masyarakat atau bangsa dan merupakan wahana dalam menerjemahkan pesan-pesan konstitusi serta sarana dalam membangun watak bangsa (nation character building). Masyarakat yang cerdas akan memberi nuansa kehidupan yang cerdas pula, dan secara progresif akan membentuk kemandirian dan masyarakat yang demikian merupakan investasi besar untuk berjuang keluar dari krisis dan menghadapi dunia global.9

Peningkatan kualitas sumber daya manusia merupakan syarat mutlak untuk mencapai tujuan pembangunan. Salah satu wahana untuk meningkatkan kualitas sumber daya manusia tersebut adalah melalui pendidikan dengan berbagai program yang dilakukan secara sistematis dan terarah berdasarkan kepentingan yang mengacu pada kemajuan ilmu pengetahuan dan teknologi (IPTEK) dan dilandasi oleh keimanan dan ketaqwaan (IMTAQ). Untuk mewujudkan hal tersebut, maka visi misi dan strategi kepemimpinan kepala madrasah dalam upaya meningkatkan mutu pendidikan tidak dapat dikesampingkan, sebab visi misi dan strategi kepemimpinan kepala merupakan kemampuan seseorang dalam mengelola dan memanfaatkan semua sumber daya yang ada di madrasah maupun di luar madrasah. Visi misi dan strategi yang baik diharapkan dapat dilakukan secara efektif dan efisien sehingga input, proses dan output yang dihasilkan benar-benar bermutu atau berkulaitas seperti guru dan siswa memiliki pengetahuan dan perubahan baik sikap, prilaku serta pola fikir yang lebih kritis baik, baik pada aspek kognitif, apektif maupun psikomotoriknya. Hal ini sangat sejalan dengan tujuan pendidikan nasional yang ingin dicapai yaitu:

\footnotetext{
${ }^{9}$ E. Mulyasa, Manajemen Berbasis Sekolah: Konsep, Strategi dan Implementasi (Bandung: PT. Remaja Rosdakarya, 2004), 4.
} 
Dalam Undang-undang Sistem Pendidikan Nasional (Sisdiknas) Nomor 20 tahun 2003 dijelaskan bahwa tujuan pendidikan nasional pada dasarnya adalah bertujuan untuk berkembangnya potensi peserta didik agar menjadi manusia Indonesia yang seutuhnya yaitu manusia yang beriman dan bertakwa kepada Tuhan Yang Maha Esa, memiliki pengetahuan dan keterampilan, berbudi pekerti yang luhur, sehat jasmani dan rohani, cakap, kreatif, cerdas, mandiri dan menjadi warga negara yang demokratis serta bertanggungjawab. ${ }^{10}$

Dengan demikian, maka kepemimpinan kepala madrasah dalam upaya meningkatkan mutu pendidikan sangat penting dilakukan. Sebab bermutu atau tidaknya pendidikan yang dihasilkan, sangat ditentukan oleh kemampuan membangun strategi dan mengimplementasikan visi misinya sebagai seorang pemimpin di lembaga madrasah. Strategi kepemimpinan merupakan sesuatu yang harus ada dan melekat pada diri seseorang pemimpin khususnya kepala madrasah. Bahkan kemampuan dalam mengatur strategi kepemimpinan tersebut menjadi salah satu faktor yang menentukan keberhasilan pembelajaran yang dilakukan di madrasah.

Bertolak dari paparan latar belakang di atas, peneliti tertarik untuk meneliti kepemimpinan kepala madrasah di Madrasah Tsanawiyah Satu Atap Mikrajussibyan NW Selanglet, Desa Penujak, Kecamatan Praya Barat, Kabupaten LombokTengah. Penelitian pada madrasah ini peneliti anggap penting untuk menjadi percontohan dalam upaya peningkatan mutu pendidikan yang dilakukan oleh lembaga madrasah lain.

\footnotetext{
${ }^{10}$ Depdiknas, Undang-Undang Nomor 20 Tahun 2003 Tenteng Sistem Pendidikan Nasional (Jakarta: Direktorat Jendral pendidikan dan Kebudayaan, 2003), 6.
} 


\section{METODE PENELITIAN}

Penelitian ini menggunakan pendekatan kualitatif. Jenis penelitian ini adalah penelitian study kasus yaitu berusaha menemukan makna, menyelidiki proses, dan memperoleh pengertian dan pemahaman yang mendalam dari individu, kelompok atau situasi dan Penelitian ini menggunakan pendekatan kualitatif, yaitu berusaha mendapatkan informasi selengkap mungkin terutama kaitannya dengan kepemimpinan kepala madrasah dalam meningkatkan mutu pendidikan yang yang terfokus pada implementasi visi, misi dan strategi kepala madrasah dalam meningkatkan mutu pendidikan. Teknik kualitatif dipakai untuk menggambarkan realitas empiris sesuai fenomena secara rinci dan tuntas, serta untuk mengungkapkan gejala secara holistik melalui pengumpulan data dari latar alami dengan memanfaatkan diri peneliti sebagai instrumen kunci. Proses wawancara mendalam bersifat sangat utama dalam pengumpulan data guna memperoleh gambaran peran kepemimpinan kepala madrasah dan implementasi visi, misi serta strategi kepemimpinan kepala madrasah dalam meningkatkan mutu pendidikan di Madrasah Tsanawiyah Satu Atap Mikrajussibyan NW Selanglet. Adapun lokasi Madrasah Tsanawiyah Satu Atap yang berada dibawah naungan Yayasan Pondok Pesantren Mikrajussibyan NW yang beralamat di Desa Penujak Kecamatan Praya Barat Kabupaten Lombok Tengah Provinsi Nusa Tenggara Barat

Teknik Analisis Data yang digunakan, menurut Miles dan Huberman, yang dikutip oleh moleong mengemukakan bahwa aktivitas dalam analisis data kualitatif dilakukan secara interaktif dan berlangsung secara terus-menerus sampai tuntas, sehingga datanya jenuh. Ukuran kejenuhan data ditandai dengan tidak diperolehnya lagi data atau informasi baru. Aktivitas dalam analisis meliputi: reduksi data (data reduction); penyajian data (data display); serta penarikan kesimpulan dan verifikasi (conclusion drawing/verification). 


\section{HASIL PENELITIAN DAN PEMBAHASAN}

\section{Hasil}

Berdasarkan hasil observasi peneliti di lapangan menunjukkan bahwa kepala madrasah melakukan peninjauan kembali visi yang telah dibuat dengan mengundang bapak/ibu guru sebagai penggerak dan pelaksana visi tersebut. ${ }^{11}$ Hasil observasi tersebut diperkuat dengan hasil dokumentasi dan wawancara peneliti dengan kepala madrasah. Hasil dokumentasi menunjukkan bahwa kepala madrasah telah melakukan peninjaun kembali terhadap visi yang telah dibuat sebelumnya. Visi awalnya: Terbina dalam akhlaq, terdepan dalam prestasi, dan berwawasan lingkungan. Setelah ditinjau ulang, berubah menjadi: "Terwujudnya Madrasah Berstandar Nasional Yang Handal dan Islami”. ${ }^{12}$

Begitu pula yang ditunjukkan oleh hasil wawancara peneliti dengan nara sumber, yaitu kepala madrasah, wakil kepala madrasah (bidang kurikulum, kesiswaan, sarana parasarana, dan humas), dan bapak ibu guru Madrasah Tsanawiyah Satu Atap Mikrajussibyan NW Selanglet.

Kepala madrasah mengatakan bahwa:

Ketika pertama kali memimpin Madrasah Tsanawiyah Satu Atap Mikrajussibyan NW Selanglet, maka langkah pertama yang saya lakukan adalah meninjau ulang visi dan misi Madrasah. Ini saya lakukan karena perumusan visi merupakan sesuatu yang sangat penting dan perlu ditinjau terlebih dahulu. Dalam melakukan peninjauan kembali visi tersebut, waktu itu saya melibatkan komite madrasah karena untuk penyusunan dokumen satu K13, di sana kan ada unsur visi dan misi, ini yang saya lakukan pertama." 13

${ }^{11}$ Observasi, Di Ruang Kantor Madrasah Tsanawiyah Satu Atap Mikrajussibyan NW Selanglet, Pada Tanggal 4 April 2016.

${ }_{12}$ Dokumentasi, Visi Madrasah Madrasah Tsanawiyah Satap Mikrajussibyan NW Selanglet, dikutip pada tanggal 4 April 2016.

${ }^{13}$ Wawancara dengan Ahmad Jayadi, Kepala Madrasah Tsanawiyah Satap Mikrajussibyan NW Selanglet, pada tanggal, 18 April 2016. 
Lebih lanjut, kepala madrasah mengungkapkan bahwa:

Saya mengambil visi dengan tiga kunci: standar nasional, handal, kemudian islami. Yang saya inginkan bahwa madrasah ini dari sisi prestasi dikenal orang dan sebagainya sudah banyak dikenal orang tetapi saya menginginkan terstandar nggak?! Jadi artinya, ada di PP 19 tahun 2005 itu kan ada beberapa standar, saya ingin coba lihat SKL-nya sampai standarstandar yang lain, nah ini yang menjadi cantolan saya ketika saya mengatakan bahwa madrasah saya ini memang standarnya sudah nasional, dan itu bukan kata orang orang tetapi secara yuridisnya ada landasannya. Nah itu cantolan saya."14

Untuk mengetahui strategi kepala madrasah dalam meningkatkan mutu pendidikan di Madrasah Tsanawiyah Satu Atap Mikrajussibyan NW Selanglet, berikut peneliti paparkan hasil wawancara, observasi, dan dokumentasi.

Berdasarkan Peraturan Pemerintah Nomor 19 tahun 2006 tentang Standar Nasional Pendidikan, maka sejak tahun 2006 Madrasah Tsanawiyah Satu Atap Mikrajussibyan NW Selanglet menerapkan Kurukulum 2013 (K13). Adapun usaha meningkatkan mutu kurikulum kepala madrasah mengadakan penambahan jam pelajaran dan memilih guru-guru yang sesuai dengan latar belakang pendidikannya. Hal itu terungkap dari uraian beliau sebagai berikut:

Pertama, secara kuantitas ada jam tambahan, kalau dilihat dari struktur kurikulum di MTs kelas III itu mungkin hanya 38 atau 40 jam, tapi di sini lebih dari itu. Kemudian pemilihan guru-guru yang sesuai dengan back ground-nya. ${ }^{15}$

Kepala juga menghendaki agar kurikulum yang digunakan disusun dengan baik dan lengkap sesuai dengan ketentuan standar nasional. Untuk itu, ketika peneliti menanyakan strateginya dalam meningkatkan mutu pendidikan, Wakil

\footnotetext{
${ }^{14}$ Ibid.

${ }^{15}$ Wawancara dengan Ahmad Jayadi Kepala Madrasah Tsanawiyah Satap Mikrajussibyan NW Selanglet pada tanggal 4 Mei 2016.
} 
Kepala I Bidang Kurikulum dan Pembelajaran, Bapak Azkar Nawawi SPd, menjelaskan:

Jadi yang pertama saya mulai dari menyusun kurikulum. Karena bagaimanapun penyusunan kurikulum dan perangkat-perangkat kurikulum itu akan menjadi pijakan untuk pengembangan kurikulum lebih lanjut. Perangkat kurikulum itu mulai dari dokumen 1, menyangkut visi, misi, struktur program kurikulum, kemudian kalender akademiknya, aturan kenaikan kelas, kelulusan, dan sebagainya. Jadi saya mulai dari kurikulum acuannya dulu kemudian saya terjemahkan dalam KTSP-nya Madrasah Tsanawiyah Satu Atap Mikrajussibyan NW Selanglet dari situ baru kita mencatat ke dalam silabus, baru penyusunan promes, prota, RPP sampai dengan masalah penilaian."16

Dari uraian tersebut dapat diketahui bahwa kepala madrasah menghendaki agar kurikulum yang digunakan memiliki pijakan aturan yang kuat dan terstandar

Kurikulum di atas merupakan kurikulum yang digunakan saat ini. pada tahun-tahun mendatang pengembangan kurikulum sangat mungkin dilakukan selaras dengan kebutuhan kurikulum yang baru. Saat ini Madrasah juga telah melakukan pengembangan kurikulum secara bertahap dan terprogram terutama yang menyangkut 4 aspek, yaitu: Perangkat pembelajaran, Model pembelajaran, Teknik-teknik evaluasi hasil belajar dan bentuk pelaporannya, dan Model-medel pengembangan dari menyesuaikan dengan perkembangan teori-teori pembelajaran baru yang berkembang di dunia pendidikan ${ }^{17}$

Adapun untuk pembelajaran, kepala madrasah menekankan pentingnya usaha untuk memenuhi standar proses yaitu dengan cara melengkapi perangkat pembelajaran sebagaimana ditentukan oleh peraturan yang berlaku.

Kemudian standar proses juga. Dimulai dari penyusunan program, analisis hari efektif, membuat silabus, membuat RPP, penilaiannya kayak apa, ini

\footnotetext{
${ }^{16}$ Wawancara, dengan Azkar Nawawi S.Pd, Wakil Kepala Madrasah Satap Mikrajussibyan NW Selanglet pada tanggal 18 April 2016

${ }^{17}$ Dokumentasi, Data kurikulum Madrasah, Dikutip Tanggal 25 April 2016.
} 
kan bagian dari mutu pembelajaran. Tidak hanya masuk kelas aja dengan pede, tapi tetap ada persiapan-persiapan." $" 18$

Proses pembelajaran yang sarat materi menjadikan pembelajaran sering menjenuhkan para siswa dan guru. Untuk mengantisipasi hal tersebut kepala madrasah mendorong upaya-upaya kreatif dalam proses pembelajaran sehingga kendala tersebut dapat teratasi. Untuk mengatasinya, pembelajaran di kelas hendaknya dielaborasikan dengan sumber-sumber lain selain guru dan buku teks pelajaran. Hal itu sebagaimana beliau utarakan:

Saya ingin memberikan warna pada teman-teman bahwa pembelajaran itu tidak hanya dari guru dan buku-buku pelajaran. Bagaimana kita itu kreatif, inovatif dalam hal pembelajaran supaya banyaknya materi tadi sama aja. Itu upaya saya agar kejenuhan, banyaknya materi tidak menjadi sebuah kendala."19

Lebih lanjut Bapak Azkar Nawawi SPd menyatakan:

Jadi proses belajar mengajar itu sebetulnya kan harus bisa melibatkan siswa secara aktif. Sehingga dikatakan belajar itu kalau ada keterlibatan langsung dari siswa, ada aktivitas yang ditunjukkan siswa secara langsung. Sehingga kita mengupayakan bahwa pembelajaran itu seyogyanya siswa yang melakukan. Komposisinya mungkin gurunya 30 persen siswanya yang 70 persen. Sehingga orientasi pembelajaran itu benar-benar berpusat pada siswa. Kemudian ada unsur kreativitas, kreativitas ini biasa dilihat kreatifitas siswa dalam bentuk dia bisa menelurkan sesuatu, kayak atau dalam bentuk kreativitas guru dalam mengembangkan proses belajar mengajar. Pemilihan metodenya, mungkin pemilihan bentuk aktivitas siswanya, pemilihan bagaimana mempresentasikan bahan ajar, itu kan kreativitas guru." 20

\footnotetext{
${ }^{18}$ Wawancara, dengan Ahmad Jayadi S.Pd, Kepala Madrasa Tsanawiyah Satap Mikrajussibyan NW Selanglet, pada tanggal, 4 Mei 2016.

${ }^{19}$ Wawancara, dengan Ahmad Jayadi S.Pd, Kepala Madrasah Tsanawiyah Satap Mikrajussibyan NW Selanglet pada tanggal 4 Mei 2016.

${ }^{20}$ Wawancara, dengan Azkar Nawawi S.Pd, Wakil Kepala Bidang Kurikulum Madrasah Tasanawiyah Satap Mikrajussibyan NW Selanglet, Pada Tanggal, 18 April, 2016.
} 
Upaya-upaya kreatif yang dikehendaki oleh kepala madrasah di antaranya dengan prasarana penunjang yang telah dimiliki Madrasah seperti bacaan-bacaan yang ada diperpustakaan, bahan-bahan dari internet, dan lain-lain. Fasilitasfasilitas penunjang pembelajaran ini telah diupayakan oleh kepala madrasah dengan selengkap dan sebaik mungkin. Selain buku pelajaran, perpustakaan menyediakan buku-buku umum, koran, tabloid, dan majalah-majalah. Perpustakaan juga menyiapkan berbagai macam film dokumenter dan keilmuan yang disediakan dalam bentuk compact disk dan dapat dipinjam oleh siswa. Untuk internet, mereka telah menyediakan laboratorium komputer yang sangat besar yang terhubung langsung dengan internet. Perkebunan dan pertamanan juga menyediakan berbagai macam tanaman yang sangat mendukung pembelajaran di kelas. Terkait dengan hal ini, Bapak Azkar Nawawi, S.Pd., menyatakan:

Pengadaan yang ada di Madrasah ini diupayakan menunjang pembelajaran. Diupayakan pengadaan tanaman itu dikaitkan dengan IPA, termasuk patung-patung, dan sebagainya., 21

Berdasarkan paparan tersebut dapat disimpulkan bahwa strategi kepala madrasah dalam bidang kurikulum dan pembelajaran, yaitu dengan cara menambah jam pembelajaran dan memberikan tupoksi guru-guru sesuai dengan pendidikannya, dan menambah sarana prasarana pendidikan.

\section{Strategi Kepala Madrasah di Bidang Kesiswaan}

Seperti disampaikan pada bagian terdahulu bahwa Madrasah Tsanawiyah Satu Atap Mikrajussibyan NW Selanglet merupakan salah satu lembaga pendidikan Islam yang banyak diminati oleh masyarakat. Berdasarkan data statistik Madrasah, jumlah pendaftar di Madrasah Tsanawiyah Satu Atap Mikrajussibyan NW Selanglet setiap tahunnya berkisar antara 30 sampai 40 anak, ruang kelas untuk belajar tersedia Cuma 6 kelas jadi tidak berani kita terima anak lebih dari itu terkait karena masih keterbatasan ruang belajar. Untuk tahun ajaran 2016/2017 menurut keterangan Wakil Kepala madrasah Bidang Kesiswaan jumlah siswa yang diterima hanya 40 orang anak dari tiga dusun yaitu selanget,

\footnotetext{
${ }^{21}$ Wawancara, dengan Azkar Nawawi S.Pd, Wakil Kepala Madrasah Satap Mikrajussibyan NW Selanglet pada tanggal 5 Mei 2016
} 
mentokok dan karang baru. hal ini dilakukan sebagai salah satu bentuk peningkatan mutu pendidikan terutama terkait dengan input siswa yang bermutu. Perkembangan siswa setiap tahunnya dapat dilihat di lampiran.

Terkait dengan penerimaan siswa baru, Waka Bidang Kesiswaan dan Kehumasan bahwa Madrasah Tsanawiyah Satu Atap Mikrajussibyan NW Selanglet menyatakan telah memiliki prosedur tetap untuk penerimaan siswa baru yang dilaksanakan lebih awal dan Madrasah-Madrasah lainnya. Jumlah siswa yang diterima pada tiap tahun ajaran baru berbeda-beda. Hal ini disebabkan Madrasah Tsanawiyah Satu Atap Mikrajussibyan NW Selanglet belum mengadakan penambahan lokal kelas yang dimiliki dari 6 kelas yang tersedia ini. Madrasah belum mengupayakan penambahan lokal karena lebih mempertimbangkan efektivitas pembelajaran. Beliau menuturkan:

Kami itu punya 6 kelas, untuk kelas I, II dan III masing-masing 2 kelas. Jadi ketika kelas III keluar kami hanya bisa menerima siswa ukuran 2 kelas sekitar 30 atau 40 orang anak. Kami sesuaikan dengan lokal yang ada , tidak ada penambahan lokal baru. Ini dulu dibina. Masyarakat tidak bertanya lagi Madrasah Tsanawiyah Satu Atap itu butuh murid berapa."22

Besarnya animo masyarakat untuk menyekolahkan anaknya di Madrasah Tsanawiyah Satu Atap Mikrajussibyan NW Selanglet menjadikan Madrasah ini memiliki banyak pilihan untuk menentukan input siswa yang akan masuk sebagai siswa baru. Hal ini tentu menjadi keuntungan tersendiri demi menjaga mutu kesiswaan utamanya input dan output siswa nantinya. Berdasarkan hasil observasi menunjukkan bahwa setelah proses rekrutmen selesai, siswa yang diterima selanjutnya dibagi atas tiga kelompok besar, yaitu:

(1) kelompok siswa berkualitas; (2) kelompok siswa berkualitas sedang; dan (3) kelompok siswa berkualitas rendah. Masing-masing kelas nantinya akan diisi oleh ketiga kelompok tersebut. Jadi, sistem yang

\footnotetext{
${ }^{22}$ Wawancara dengan Akhyar Rosidi S.Pd, Wakil Kepala Bidang Kesiswaan Madrasah Tsanawiyah Satu Atap Mikrajussibyan NW Selanglet pada Tanggal 18 April 2016.
} 
digunakan dalam penyebaran siswa adalah sistem kelas heterogen. Hal ini dilakukan demi menjaga dinamika belajar yang kompetitif." 23

Terkait dengan upaya menghasilkan output yang bermutu Waka bidang kesiswaan Akhyar Rosidi S.Pd. menuturkan:

Yang pertama bahwa kita mengandalkan dalam segi proses, jadi untuk menjaga output tetap baik ya kita harus menjaga agar prosesnya tetap baik. Untuk itu, teman-teman yang ada di sini dituntut untuk bisa mengembangkan potensi yang dimiliki oleh siswa. Guru bidang studi, harus lebih intens dan lebih bisa menambah wawasan, mengembangkan materinya di masing-masing bidang studi itu." 24

Dari uraian di atas diketahui bahwa untuk meningkatkan proses pembelajaran, Madrasah ini menggunakan kelas atau guru bidang study masing masing dan memiliki satu orang wali kelas sebagai penanggung jawab dari kelas itu sendiri. Ketika guru bidang study tidak dapat mengisi jam pelajarannya karena ada halangan, wali kelas bertanggung jawab untuk mengisi kekosongan pelajarannya. Wali kelas masing masing memiliki jadwal piket ketika guru berhalangan masuk. Wali Kelas II, Ibu Nurainun, S.Pd., menyatakan:

Semua kelas I, II dan III menggunakan guru bidang study dan satu orang wali kelas, nah wali kelas itu sebagi penanggung jawab penuh terhadap kelasnya masing-masing. Wali kelas punya jadwal piket untuk mengisi kelas-kelas yang kosong ketika guru berhalangan hadir. ${ }^{25}$

Sedangkan untuk menopang pembelajaran di kelas, Madrasah Tsanawiyah Satu Atap Mikrajussibyan NW Selanglet membuka berbagai kegiatan di luar pembelajaran yang lazim disebut UPMB (Unit Pengembangan Minat dan Bakat) yang diikuti siswa. UPMB itu adalah:

\footnotetext{
${ }^{23}$ Observasi, Ruang Kelas Madrasah Tsanawiyah Satu Atap Mikrajussibyan NW Selanglet Pada Tanggal 25 April 2016.

${ }^{24}$ Wawancara, dengan Akhyar Rosidi S.Pd, Wakil Kepala Bidang Kesiswaan, Madrasah Tsanawiyah Satu Atap Mikrajussibyan NW Selanglet, pada tanggal, 4 Mei April, 2016.

${ }^{25}$ Wawancara, dengan Ibu Nurainun, S.Pd, Wali kelas II, pada Tanggal, 5 Mei, 2016.
} 
Pramuka, Qasidah, mengarang, drama, puisi, Drum Band, bahasa inggris, qiroah dan kaligrafi, komputer, bola basket, dan sepak bola. ${ }^{26}$

Bahkan sebagai bentuk komitmen untuk membina kreatifitas anak, Madrasah juga memberi materi pelajaran Seni, Budaya, dan Ketrampilan (SBK) yang harus diikuti oleh semua siswa. Guru mata pelajaran SBK, Ibu Juraedah S.Pd, menyatakan:

Di sini karena ada pelajaran kesenian dan ketrampilan, jadi itu terdiri dari musik, tari, dan seni rupa. Saya sendiri mengajar seni musik dan suara. Ini masuk pelajaran wajib semuanya harus ikut, termasuk SBK, seni budaya dan ketrampilan."27

Adapun untuk menopang agar lulusan Madrasah ini tetap bermutu, kepala madrasah mencanangkan standar minimal 80 untuk kualifikasi ketuntasan minimum (KKM) belajar siswa. Uraian beliau:

Ketika berbicara lulusan, saya tidak hanya anak-anak lulus, mereka lulus itu nanti seperti apa daya saingnya. Ketika mereka lulus mereka bisa diterima di Madrasah-Madrasah yang memang mempunyai grade tinggi, itu kan bagian dari kualitas juga. Jadi untuk nilai pembelajaran, ya topangannya ya KKM itu. ${ }^{28}$

Terkait dengan lulusan yang diharapkan Madrasah Tsanawiyah Satu Atap Mikrajussibyan NW Selanglet mengharapkan agar lulusannya dapat memenuhi standar kompetensi lulusan, diterima di Madrasah/Madrasah favorit selanjutnya, dan menjadi insan yang mempunyai IMTAQ dan IPTEK yang tinggi dan tangguh.

Berdasarkan paparan tersebut di atas, dapat disimpulkan bahwa strategi kepala madrasah di bidang kesiswaan, yaitu dilakukan dengan dengan cara membagi siswa berdasarkan kelompok siswa berkualitas; kelompok siswa

${ }^{26}$ Dokumentasi, UPMB (Unit Pengembangan Minat dan Bakat) yang diikuti siswa, dikutip Tanggal, 18 April 2016.

${ }^{27}$ Wawancara, dengan Juraedah, S.Pd, guru SBK Madrasah Tsanawiyah Satu Atap Mikrajussibyan NW Selanglet, pada tanggal, 25 April 2016.

${ }^{28}$ Wawancara, dengan Ahmad Jayadi, S.Pd, Kepala Madrasah Tsanawiyah Satu Atap Mikrajussibyan NW Selanglet, pada tanggal, 5 mei, 2016. 
berkualitas sedang; dan kelompok siswa berkualitas rendah. Di samping itu, kepala madrasah juga menerapkan sistem guru bidang studi dan satu wali kelas untuk masing-masing kelas.

\section{Strategi Kepala Madrasah di Bidang Ketenagaan}

Sumber daya Madrasah, terutama guru, masih menjadi salah satu faktor terpenting untuk ditingkatkan mutunya. Demikian pandangan Kepala Madrasah akan pentingnya peran guru dan karyawan dalam meningkatkan mutu pendidikan di Madrasah ini. Untuk itu, para guru dan karyawan di Madrasah ini senantiasa dilatih dan diberdayakan semaksimal mungkin agar dapat membawa siswa dan lembaga Madrasah berprestasi.

Terkait dengan upaya peningkatan profesionalisme guru, beliau mengatakan:

Yang saya lakukan untuk meningkatkan profesionalisme teman teman, saya ciptakan kegiatan-kegiatan yang membuat teman teman itu terdorong untuk membiasakan berbudaya ilmiah. Jadi membaca, diskusi, lewat forum-forum kolokium, ada kegiatan kegiatan workshop-workshop, kegiatan-kegiatan yang sifatnya pemberdayaan teman-teman itu rutin setiap hari sabtu setelah anak anak pulang PMB. Sabtu itu jam 11 sudah pada pulang. Lalu guru guru pemberdayaan. ${ }^{29}$

Hal senada disampaikan oleh Koordinator Bidang Litbang, Bapak Jamilidin, SPd, yang menyatakan:

"Kalau guru itu pemberdayaannya tertulis, setiap hari sabtu. Jam 11 sampai jam 01. Peningkatan profesionalisme guru, baik untuk mata pelajarannya maupun materi materi-materi umum yang terkait dengan pendidikan. Kemudian karyawan juga begitu, dijadwal setiap hari sabtu juga. kemudian untuk siswa, kita berikan pembinaan setiap hari sabtu untuk klinik dan konsultasi. Klinik itu untuk anak-anak yang memerlukan bantuan sehingga bisa juga mengejar teman-teman yang lain. Sementara

\footnotetext{
${ }^{29}$ Wawancara, dengan Ahmad Jayadi, Kepala Madrasah Tsanawiyah Satu Atap Mikrajussibyan NW Selanglet, pada tanggal 5 Mei, 2016.
} 
konsultasi untuk kelompok-kelompok yang mandiri. Konsultasinya bisa meliputi problem-problem akademik, maupun problem sosial. ${ }^{30}$

Upaya yang dilakukan kepala dalam memberdayakan para guru dan karyawan diadakan secara rutin setiap sabtu, setelah pembelajaran berakhir. Acara tersebut berbentuk diskusi-diskusi, seminar, ataupun pelatihan bagi internal guru Madrasah Tsanawiyah Satu Atap Mikrajussibyan NW Selanglet dengan menghadirkan nara sumber dari luar seperti pengawas kecamatan. Di samping itu,, kepala juga mendorong para guru dan karyawan untuk meningkatkan kapasitas dirinya melalui berbagai seminar, pelatihan, workshop di luar MTs. Lebih dari itu, MTs juga menfasilitasi para guru dan karyawan untuk studi lanjut. Bagi sebagian guru yang berprestasi maka akan diberikan beasiswa untuk studi lanjutnya. Sampai hari ini ada 2 orang guru yang menempuh studi melalui fasilitas ini. Adapun untuk kesejahteraan guru dan karyawan maka Madrasah Tsanawiyah Satu Atap Mikrajussibyan NW Selanglet memberikan kesejahteraan sesuai dengan pendapatan Yayasan dan di ambil dari Dana BOS yang ada ditambah lagi dengan tunjangan sertifikas Guru. Di samping itu, ada pula tunjangan tetap untuk jabatan-jabatan tertentu dan kegiatan-kegiatan tertentu sesuai dengan keadaan kas yayasan. Kepala madrasah menuturkan sebagai berikut:

Kesejahteraan teman-teman kita, kita sesuaikan dengan jumlah bidang study yang diampu dan diberikan sesuai dengan keadaan dana yang ada di yayasan dan pendapatan dari dana BOS ditambah lagi dengan tunjangan profesi guru. Karena Rata-rata guru di madrasah ini adalah Swasta yaitu guru tetap yayasan dan guru tidak tetap. Dan guru-guru yang memiliki prestasi dan loyalitas tinggi terhadap lembaga diberikan kesempatan untuk melanjutkan pendidikannya dan itu di biayai dari hasil usaha-usaha yayasan.. $^{31}$

\footnotetext{
${ }^{30}$ Wawancara, dengan Jamiludin S.PdI Guru Madrasah Tsanawiyah Satu Atap Mikrajussibyan NW Selanglet, pada Tanggal, 5 Mei 2016.

${ }^{31}$ Wawancara, dengan Ahmad Jayadi S.Pd, Kepala Madrasah Tsanawiyah Satap Mikrajussibyan NW Selanglet pada Tanggal 5 Mei 2016.
} 
Dari uraian tersebut dapat disimpulkan bahwa kepala madrasah terus berupaya meningkatkan kesejahteraan SDM Madrasah dengan berbagai macam cara, di antaranya dengan cara memberikan tunjangan hari raya, dan beasiswa studi lanjut bagi bapak/ibu guru.

\section{Strategi Kepala Madrasah di Bidang Sarana dan Prasarana}

Madrasah Tsanawiyah Satu Atap Mikrajussibyan NW Selanglet memandang sarana dan fasilitas sebagai prasyarat keberhasilan proses pendidikan. Untuk itu, Madrasah ini berupaya semaksimal mungkin melengkapi sarana dan fasilitas belajar yang dibutuhkan oleh siswa dalam kegiatan pembelajarannya dengan menetapkan sasaran pencapaian sarana dan prasarana yang meliputi:

Berdasarkan hasil observasi menunjukkan bahwa di Madrasah Tsanawiyah Satu Atap Mikrajussibyan NW Selanglet, kelas bukanlah satu-satunya tempat belajar, melainkan siswa diharapkan dapat memaksimalkan sarana dan fasilitas penunjang pembelajaran yang meliputi Ruang tata usaha, ruang UKS, dan kantin, aula, mushalla, lapangan basket, dan halaman yang tamannya disetel untuk memberikan nilai tambah pembelajaran. Halaman madrasah dipakai sebagai fasilitas penunjang pembelajaran karena bersih dan luas, seperti sebagai tempat upacara dan tempat berolah raga siswa. Halaman Madrasah dikelilingi oleh taman-taman bunga dan bangku-bangku teras madrasah dan berugak sebagai tempat bersantai

mengungkapkan bahwa sarana yang mereka miliki mungkin yang terlengkap di Praya Barat. Beliau menuturkan:

Insya Allah kalau dari sarana prasana untuk untuk Madrasahmadrasah yang ada di Penujak dan di Praya Barat saya masih mengatakan bahwa Madrasah kita ini bisa dikatakan sangat lengkap. $^{32}$

Lengkapnya fasilitas ini tentunya memberi manfaat lebih kepada semua warga Madrasah, terutama siswa. Salah seorang siswa yang baru berpindah dari

\footnotetext{
${ }^{32}$ Wawancara, dengan Ahmad Jayadi S.Pd, Kepala Madrasah Tsanawiyah Satap Mikrajussibyan NW Selanglet pada tanggal 5 Mei 2016
} 
salah satu Madrasah Tsanawiyah di Praya Barat menyatakan bahwa fasilitas di Madrasah ini jauh lebih baik dan lengkap.

Di samping kelengkapan fasilitas yang dimiliki, Madrasah juga mengupayakan agar semua fasilitas yang dimiliki mempunyai tingkat keselamatan yang baik. Wakil Kepala IV Bidang Sarana dan Prasarana, Bapak Jamiludin, S.Pd, menyatakan:

Targetnya kondisi yang nyaman, tingkat keselamatannya tinggi, kemudian dari segi kebersihan harus betul betul diprioritaskan karena kebersihan juga bagian dari wujud kepedulian terhadap ajaran agama",33

Adapun beberapa sarana yang belum terpenuhi, maka kepala Madrasah mengupayakannya secara bertahap dengan skala prioritas. Prioritas utama beliau adalah buku. Bila kebutuhan akan buku telah terpenuhi maka fasilitas-fasilitas lainnya yang dirasa kurang bisa diupayakan pengadaannya. Beliau menuturkan sebagai berikut:

Ya, secara fasilitas kita berikan secara bertahap. Yang pertama adalah buku. Saya kira buku itu menjadi kebutuhan kita, lagi mengajar atau tidak mengajar. Saya ingin budaya membaca dan cinta buku ini menjadi budaya di sini. Kemudian yang kedua fasilitas. Kelas bisa menjadi lab, tetapi alangkah baiknya kita punya lab tersendiri sehingga ada moving, ada aktivitas fisik, ada oksigen bagi anak-anak untuk menyerap lebih jauh.”34

Buku dianggap kepala madrasah sebagai sumber utama belajar siswa. Untuk itu kebutuhan akan buku selalu dipenuhi dengan baik. Hal itu dilakukan dengan upaya pengadaan buku-buku setiap bulannya. Koordinator Unit Perpustakan menjelaskan sebagai berikut:

Pengadaannya rutin setiap bulan, cuma untuk pembeliannya tergantung dari kebutuhan. Jadi kita itu semacam usulan untuk

\footnotetext{
${ }^{33}$ Wawancara, dengan Jamilidin S.PdI Wakil Kepala Bidang Sarana Prasarana, Madrasah Tsanawiyah Satu Atap Mikrajussibyan NW Selalanglet, pada tanggal, 4 Mei, 2016.

${ }^{34}$ Wawancara, dengan Ahmad Jayadi S.Pd, Kepala Madrasah Tsanawiyah Satap Mikrajussibyan NW Selanglet, pada tanggal, 18 April 2016.
} 
kolesi, jadi guru-guru butuhnya apa, karena yang lebih tahu kan gurunya ya. Untuk buku-buku umum apa, pelajaran apa, referensi, ensiklopedi apa, langsung kita adakan. Yang jelas anggarannya ada setiap bulan, Cuma pembeliannya tergantung pada kebutuhan."35

Fasilitas penunjang seperti koran, majalah, komputer, dan internet senantiasa diupayakan pengadaannya oleh kepala madrasah. Bahkan beliau mengupayakan hal-hal yang dianggap penting secara maksimal, misalnya seperti internet. Beliau mengatakan:

Kemudian, sumber belajar yang sudah ada di mana-mana, tinggal bagaimana guru itu mampu mengakses karena itu internet di sini sudah ada hotspotnya yang bisa diakses selama 24 jam kalau perlu. Anak-anak kelas III kita tambah pakai LCD. Teman-teman yang tidak punya laptop kita sediakan laptop di lab komputer untuk pembelajaran di sana." 36

Berdasarkan paparan tersebut di atas, dapat disimpulkan bahwa strategi kepala madrasah dalam bidang sarana prasarana yaitu dengan berupaya menambah sarana prasarana dan mengoptimalkan sarana prasarana yang ada sebagai penunjang pembelajaran dan kelengkapan fasilitas yang dimiliki oleh Madrasah telah digunakan dengan baik oleh para siswa.

\section{PEMBAHASAN}

Kurikulum adalah semua pengalaman belajar yang diperoleh peserta didik di bawah pengawasan atau bimbingan madrasah. Pengalaman belajar dimaksud seringkali dikelompokkan dan disebut bidang studi atau mata pelajaran, yang harus diajarkan kepada peserta didik. ${ }^{37}$ Pengalaman di atas terdiri atas (1) semua

\footnotetext{
${ }^{35}$ Wawncara, dengan M. Suba i Kepala Tata Usaha, Madrasah Tsanawiyah Satu Atap Mikrajussibyan NW Selanglet, pada tanggal, 18 April 2016.

${ }^{36}$ Wawancara, dengan Ahmad Jayadi S.Pd, Kepala Madrasah Tsanawiyah Satap Mikrajussibyan NW Selanglet pada tanggal 4 Mei, 2016

${ }^{37}$ Mulyani, Kurikulum dan Pembelajaran (Jakarta: Ditjen Pendidikan Tinggi, 1988), 95.
} 
pengalaman di dalam kelas (in school experiences) dan (2) pengalaman belajar di luar madrasah (community resources). ${ }^{38}$

Kurikulum madrasah mengacu pada standar isi pendidikan dan dapat dikembangkan dengan mengacu pada prinsip pengembangan kurikulum mencakup: relevansi, keefektifan dan efisiensi, kesinambungan, fleksibilitas, dan berorientasi pada tujuan.

Madrasah Tsanawiyah Satu Atap Mikrajussibyan NW Selanglet sebagai madrasah unggul telah sama-sama menerapkan Kurukulum Tingkat Satuan Pendidikan (KTSP), menambah jam pelajaran, dan mendorong upaya-upaya kreatif guru dan siswa dalam proses pembelajaran dengan mengelaborasikan sumber-sumber belajar.

Madrasah Tsanawiyah Satu Atap Mikrajussibyan NW Selanglet juga meningkatkan pembelajarannya dengan memenuhi standar proses dan melengkapi perangkat pembelajaran dengan ditopang guru-guru yang sesuai dengan latar belakang pendidikannya. Untuk mengoptimalkan usaha tersebut Kepala Madrasah mendorong upaya kreatif dalam proses pembelajaran dengan mengelaborasikan sumber-sumber belajar. Hal ini dilakukan untuk mendorong anak mendapatkan pengalaman belajar semaksimal mungkin dan berprestasi belajar setinggi mungkin.

Dengan pembelajaran seperti ini Kepala Madrasah senantiasa memberi motivasi berprestasi dan berkompetisi pada anak didik. Dalam Pembelajaran seperti ini Setiap peserta didik didorong untuk mempunyai keinginan untuk menunjukkan prestasi dan berkompetensi dengan berusaha menaklukkan lingkungannya. Hal ini sesuai dengan ciri motivasi belajar yang tidak lepas dari keinginannya untuk menunjukkan kemampuan yang dimilikinya.

Kepala Madrasah Tsanawiyah Satu Atap Mikrajussibyan NW Selanglet juga berupaya mengembangkan kurikulum secara fleksibel yang merupakan salah satu prinsip pengembangan kurikulum yang mengarah pada upaya penyesuaianpenyesuaian dengan kebutuhan anak didik. Dalam proses pembelajarannya

\footnotetext{
${ }^{38}$ Marno, Islam by Management and Leadership: Tinjauan Teoritis dan Empiris Pengembangan Lembaga Pendidikan Islam (Surabaya: Lintas Pustaka, 2007), 135-156.
} 
madrasah ini mengoptimalkan pelayanan terhadap anak dengan pendekatan kelompok yang didampingi oleh gurunya.

Dalam pembelajaran, Kepala Madrasah menekankan proses belajar yang menyenangkan. Guru dituntut untuk kreatif dan fleksibel. Kepada peneliti, kepala menyatakan bahwa guru di madrasah ini tidak diperkenankan memarahi anak. Harapannya, pembelajaran dapat mengalir lebih hangat dan akrab dan penuh ceria.

Model pembelajaran seperti ini, sebagaimana dikatakan oleh Gagne, akan menimbulkan model belajar responden. Dalam model belajar ini, suatu respon dikeluarkan oleh suatu stimulus yang telah dikenal. Jadi, terjadinya proses belajar dikarenakan adanya stimulus. Misalnya Maya bisa menjawab pertanyaan yang diberikan oleh gurunya dengan benar. Kemudian guru tersebut memberikan senyuman dan pujian kepadanya. Akibatnya Maya semakin giat belajar. Senyum dan pujian guru ini merupakan stimulus tak terkondisi. Tindakan guru ini menimbulkan perasaan yang menyenangkan pada diri Maya sehingga ia membuat dia lebih giat lagi dalam belajar.

Kepala Madrasah Tsanawiyah Satu Atap Mikrajussibyan NW Selanglet menghendaki agar pembelajaran tidak selalu dilakukan di kelas. Anak bisa diajak belajar di mana aja. Pembelajaran dimulai ketika siswa telah siap untuk belajar. Pembelajaran seperti ini menganut prinsip kesiapan (readiness). Proses belajar sangat dipengaruhi oleh kesiapan individu sebagai subyek yang melakukan kegiatan belajar. Kesiapan belajar adalah kondisi fisik-psikis (jasmani-mental) individu yang memungkinkan subyek dapat belajar. Lebih dari itu, sesungguhnya model pembelajaran yang digunakan di Madrasah Tsanawyah Satu Atap Mikrajussibyan NW Selanglet telah memenuhi lima ciri pengajaran Quantum Teaching, yang meliputi 39: (1) adanya unsur demokrasi dalam pengajaran; (2) sebagai akibat dari ciri yang pertama, maka memungkinkan tergali dan terekspresikannya seluruh potensi dan bakat yang terdapat pada anak; (3) adanya kepuasan pada diri anak; (4) adanya unsur pemantapan dalam menguasai materi

\footnotetext{
${ }^{39}$ Abbuddin Nata, Manajemen Pendidikan: Mengatasi Kelemahan Pendidikan Islam Indonesia. (Jakarta: Prenada Media, 2003), 37.
} 
atau suatu keterampilan yang diajarkan; dan (5) Kelima, adanya unsur kemampuan pada seorang guru dalam merumuskan temuan yang dihasilkan anak, dalam bentuk konsep, teori, model dan sebagainya.

Dari beberapa uraian di atas diketahui bahwa Madrasah Tsanawiyah Satu Atap Mikrajussibyan NW Selanglet telah berupaya mendorong siswa untuk memanfaatkan pengalaman di dalam kelas (in school experiences) dan pengalaman belajar di luar madrasah (community resources) sebagai bahan untuk belajar. Untuk mengevaluasi yang kedua, Madrasah Tsanawiyah Satu Atap Mikrajussibyan NW Selanglet membuat buku evaluasi harian siswa dengan mengandalkan kerjasama para wali murid.

Pembelajaran yang demikian menurut Bafadal, merupakan indikator pembelajaran yang unggul berpusat pada siswa (student center) yang berupaya melayani semua siswa (bukan hanya pada sebagian siswa). Dengan model pembelajaran unggul, semua anak mendapatkan pengalaman belajar semaksimal mungkin. Meski mengupayakan agar semua siswa mendapatkan pengalaman belajar maksimal, prosesnya sangat bervariasi bergantung pada tingkat kemampuan anak yang bersangkutan. 40

Strategi Kepala Madrasah Dibidang Kesiswaan

Tujuan pembinaan kesiswaan sebagaimana diamanatkan dalam Permendiknas nomor 39 tahun 2008 tentang Pembinaan Kesiswaan adalah mengembangkan potensi siswa secara optimal dan terpadu yang meliputi bakat, minat, dan kreativitas. Untuk mencapai tujuan di atas kepala Madrasah Tsanawiyah Satu Atap Mikrajussibyan NW Selanglet berupaya menyeleksi input siswa dengan ketat dan mempertahankan kuantitas siswa dengan pertimbangan efektivitas pembelajaran.41

Madrasah Tsanawiyah Satu Atap Mikrajussibyan NW Selanglet telah memiliki prosedur tetap untuk penerimaan siswa baru yang dilaksanakan lebih awal dan madrasah-madrasah lainnya. Jumlah siswa yang diterima pada tiap tahun

\footnotetext{
${ }^{40}$ Ibrahim Bafadhal, Manajemen Peningkatan Mutu Madrasah Dasar; dari Sentralisai Menuju Desentralisasi, (Jakarta: Bumi Aksara, 2003), 30.

${ }^{41}$ Permendiknas Nomor 39 Tahun 2008, Tentang Pembinaan Kesiswaan.
} 
ajaran baru berbeda-beda karena madrasah belum mengadakan penambahan lokal kelas yang dimiliki dari 6 kelas yang tersedia ini. Madrasah belum mengupayakan penambahan lokal karena lebih mempertimbangkan efektivitas pembelajaran.

Besarnya animo masyarakat untuk menyekolahkan anaknya di Madrash Tsanawiyah Satu Atap Mikrajussibyan NW Selanglet menjadikan madrasah ini memiliki banyak pilihan untuk menentukan input siswa yang akan masuk sebagai siswa baru. Hal ini tentu menjadi keuntungan tersendiri demi menjaga mutu kesiswaan utamanya input dan output siswa nantinya.

Untuk memulai proses pendidikan, Kepala Madrasah membagi siswa atas tiga kelompok besar, yaitu: (1) berkualitas tinggi; (2) berkualitas sedang; dan (3) berkualitas rendah dan membaginya dalam kelas heterogen.

Adapun terkait dengan proses, maka pada tahap ini Kepala Madrasah menghendaki adanya pengembangan kreativitas anak baik dari segi kecerdasan intelektualnya, emosionalnya, maupun spiritualnya. Sehingga dimadrasah ini anak tidak hanya belajar mata pelajaran saja tetapi juga pada ranah sosial dan religiusitasnya.

Upaya di atas dibantu dengan mengedepankan proses belajar yang menyenangkan anak dengan ditopang oleh kerja-kerja kelompok. Kepala menekankan agar pembelajaran dilangsungkan dengan tanpa membebani siswa tapi justru menyenangkan mereka. Untuk itu guru di madrasah ini dituntut untuk selalu kreatif mengembangkan metode pembelajaran yang digunakannya dalam membimbing para siswa dalam kelompoknya masing- masing. Ini sesuai dengan konsep yang dikemukakan oleh Dimyati, bahwasannya dalam pembelajaran melalui kelompok kecil, guru dapat memberikan bantuan kepada siswa atau bimbingan kepada tiap anggota kelompok lebih intensif.42 Hal ini dapat terjadi, karena: (1) hubungan antara guru dan siswa menjadi sehat dan akrab, (2) siswa memperolah bantuan, kesempatan, sesuai dengan kebutuhan, kemampuan, dan minat, (3) siswa dilibatkan dalam penentuan tujuan belajar, cara belajar, kriteria keberhasilan.

\footnotetext{
${ }^{42}$ Dimyati, dkk., Belajar dan Pembelajaran (Jakarta: Rineka Cipta, 1999), 165.
} 
Pembelajaran ini merupakan perbaikan dari kelemahan pembelajaran klasikal. Adapun tujuan pembelajaran pada kelompok kecil ini menurut Dimyati, meliputi 4 hal, yaitu: (1) memberi kesempatan kepada setiap siswa untuk mengembangkan kemampuan memecahkan masalah secara rasional, (2) mengembangkan sikap sosial dan semangat bergotong royong dalam kehidupan, (3) mendinamiskan kegiatan kelompok dalam belajar, sehingga tiap anggota merasa dirinya sebagai bagian dari kelompok yang bertanggung jawab, dan (4) mengembangkan kemampuan kepemimpinan dan keterpimpinan pada tiap anggota kelompok dalam pemecahan masalah kelompok.

Di samping mengarahkan dan membimbing para murid agar semakin meningkat pengetahuannya, semakin mahir keterampilannya, dan semakin terbina dan berkembang potensinya, guru dituntut mampu melaksanakan inspiring teaching. Dalam model pembelajaran ini, guru, melalui kegitan mengajarnya mampu mengilhami murid-muridnya. Melalui kegiatan mengajar yang dilakukannya seorang guru mampu mendorong para siswa agar mampu mengemukakan ide, gagasan, dan kreasi murid-muridnya.

Dengan model pembelajaran pembelajaran kelompok yang dikembangkan di madrasah ini, sesungguhnya Madrasah Tsanawiyah Satu Atap Mikrajussibyan NW Selanglet telah mengajarkan kepada anak untuk bersosialisasi dengan teman dan rekan sejawat. Dalam model pembelajaran ini madrasah ini menggunakan empat model sekaligus, yaitu task planning groups, seating groups, join learning groups, dan collaborative-group. Model ini diterapkan sepanjang semester yang menitikberatkan pada kerjasama tiap individu dan hasilnya sebagai sesuatu yang teraplikasi. Dengan model pembelajaran seperti inilah tujuan pendidikan untuk belajar hidup bersama (leaning to live together) sebagaimana diamanatkan oleh Unesco43 yang dapat lebih mudah dicapai.

Strategi Kepala Madrasah Dibidang Ketenagaan.

Mutu pendidikan selalu terkait dengan masalah sumber daya manusia yang terdapat dalam lembaga pendidikan tersebut. Masalah sumber daya manusia

${ }^{43}$ Anna Poedjiadi, Sains Teknologi Masyarakat: Model Pembelajaran Kontekstual Bermuatan Nilai (Bandung: PT Remaja Rosda Karya, 2005), 98. 
terutama di lembaga pendidikan Islam selalu mewarnai baik buruknya mutu pendidikan yang dihasilkan. Apalagi, realitas pendidikan Indonesia nampaknya masih kesulitan untuk bisa keluar dari masalah ini. Untuk itu, diperlukan strategistrategi tertentu agar mutu Sumber Daya Madrasah, dalam hal ini guru dan karyawan, dapat terdongkrak.

Secara garis besar, peningkatan profesionalisme guru dan karyawan dapat ditempuh dengan tiga program, yaitu: (1) Program preservice education; (2) Program inservice education; dan (3) Program inservice training.44

Kepala Madrasa Tsanawiyah Satu Atap Mikrajussibyan NW Selanglet telah berupaya menerapkan program inservice training dengan memberdayakan guru dan karyawan melalui kegiatan rutin di madrasah yang diisi dengan diskusi, pelatihan, dan kegiatan-kegiatan sejenis dengan mendatangkan nara sumber jika diperlukan. Kepala Madrasah mendorong para guru dan karyawan untuk meningkatkan kapasitas dirinya melalui berbagai seminar, pelatihan, workshop di luar madrasah. Terkait program inservice education, madrasah juga mendorong para guru dan karyawan untuk studi lanjut. Adapun untuk preservice education, maka madrasah belum tampak memberi program khusus terkait hal ini. Kepala Madrasah meyakini bahwa para guru telah mendapatkan pendidikan yang cukup terkait dengan profesi kependidikannya. Kepala lebih menggunakan inservice education dan inservice training untuk meningkatkan mutu guru dibanding dengan preservice education.

Di sini Kepala Madrasah banyak berperan sebagai process helpers dan resource linkers yang menurut Mulyasa, Kepala Madrasah lebih banyak membantu kelancaran proses yang dihadapi oleh guru dan karyawan, khususnya menyelesaikan masalah dan membina pihak-pihak yang terkait.45 Kepala juga banyak berperan menghubungkan orang dengan sumber daya yang ada. Untuk itu Kepala Madrasah hendaknya responsif dalam melihat kebutuhan para guru dan karyawan di madrasah.

\footnotetext{
${ }^{44}$ Piet A. Sahertian, Profil Pendidik Profesional (Yogyakarta: Andi Offset, 1994), 67.

${ }^{45}$ E. Mulyasa, KBK Konsep, Karakteristik dan Implementasi, (Bandung: PT Remaja Rosdakarya, 2003), 181.
} 
Untuk itulah, Lawler, yang dikutip dalam Sudirman Danim menyarankan agar para manajer menggunakan manajemen pelibatan tinggi (high involvement management) yang melibatkan guru dan karyawan dalam setiap aktivitas pendidikan di madrasah. Pendekatan ini akan memberi banyak manfaat bagi guru, di antaranya akan memunculkan inovasi-inovasi baru, menambah kepuasan kerja, dan keluhan-keluhan para guru akan lebih diperhatikan.46

Kepala Madrasah pada hakekatnya adalah sumber semangat bagi para guru, staf dan siswa. Oleh sebab itu Kepala Madrasah harus selalu membangkitkan semangat, percaya diri terhadap para guru dan karyawan. Untuk itu para guru dan karyawan madrasah hendaknya selalu mendapatkan saran anjuran dari Kepala Madrasah sehingga dengan saran tersebut selalu dapat memelihara bahkan meningkatkan semangat dan motivasi dalam melaksanakan tugas masing-masing.

Untuk menunjang pengembangan profesionalisme guru tersebut di atas, kepala madrasah telah berupaya memperhatikan kebutuhan dasar guru dan karyawan, terutama yang berkaitan dengan kesejahteraan hidupnya. Kebutuhan dasar guru sebagaimana dikatakan oleh Bafadal,yang meliputi (1) Kebutuhan fisik; (2) Kebutuhan rasa aman; (3) Kebutuhan sosial; (4) Kebutuhan harga diri (penilaian diri); (5) Kebutuhan aktualisasi diri (keamanan sesorang untuk mengembangkan dan merealisasikan kemampuannya)47 telah diupayakan dengan baik oleh madrasah.

Kepala Madrasah Tsanawiyah Satu Atap Mikrajussibyan NW Selanglet berupaya memberi gaji yang layak sesuai dengan pendapatan madrasah dan yayasan. Konsekuensi dari system ini adalah guru dan karyawan baik yang tetap maupun yang tidak tetap mendapat tugas dan tanggung jawab yang relatif sama sehingga kecemburuan sosial antara guru dan karyawan lebih dapat ditekan.

Di Madrasah Tsanawiyah Satu Atap Mikrajussibyan NW Selanglet, Kepala Madrasah juga berupaya memenuhi kebutuhan aktualisasi diri para guru

\footnotetext{
${ }^{46}$ Sudirman Danim, Visi Baru Manajemen Madrasah., Ibid., hal. 159

${ }^{47}$ Ibrahim Bafadal, Supervisi Pengajaran: Teori dan Aplikasinya dalam Membina Profesionalisme Guru (Bumi Aksara: Jakarta, 1992), 64.
} 
dan karyawan. Pemenuhan akan kebutuhan ini diberikan dengan cara menempatkan mereka yang berprestasi pada jabatan-jabatan dan posisi-posisi tertentu di madrasah. Beberapa guru yang berprestasi lebih, madrasah memberi beasiswa untuk studi lanjut sebagai bentuk kebutuhan harga diri dan sosial. Penempatan posisi tentunya tetap mengarah pada prinsip "the right man on the right place".

Di samping kebutuhan fisik sebagaimana peneliti sebutkan di atas, Kepala Madrasah juga memberi tunjangan dan fasilitas-fasilitas sebagaimana peneliti paparkan di bab sebelumnya.

Strategi kepala madrasah dibidang Sarana dan Prasarana

Sarana dan prasarana adalah alat, metode dan teknik yang dipergunakan dalam rangka meningkatkan efektivitas komunikasi dan interaksi edukatif antara guru dan siswa dalam proses pendidikan dan pengajaran di madrasah. Dalam upaya meningkatan sarana perlu diperhatikan hal-hal berikut: (1) mengerti secara mendalam tentang fungsi atau kegunaan media pendidikan, (2) mengerti penggunaan media pendidikan secara tepat dalam interaksi belajar mengajar, (3) pembuatan alat-alat media harus mudah dan sederhana, (4) memilih media yang tepat sesuai dengan tujuan dan isi materi yang diajarkan.

Sebuah lembaga pendidikan sekurang-kurangnya memiliki prasarana yang meliputi: ruang kelas, ruang perpustakaan, laboratorium IPA, ruang pimpinan, ruang guru, tempat beribadah, ruang UKS, jamban, gudang, ruang sirkulasi, dan tempat bermain/berolahraga.

Kepala Madrasah Tsanawiyah Satu Atap Mikrajussibyan NW Selanglet telah berusaha memenuhi sarana dan prasarana yang dibutuhkan oleh warga madrasah, terutama siswa. Kelengkapan sarana madrasah didukung oleh kelengkapan SDM yang ahli dalam mengaplikasikan sarana yang ada. Hal ini dikarenakan Madrasah Tsanawiyah Satu Atap Mikrajussibyan NW Selanglet memandang sarana dan fasilitas sebagai prasyarat keberhasilan proses pendidikan. Untuk itu, madrasah ini berupaya semaksimal mungkin melengkapi sarana dan fasilitas belajar yang dibutuhkan oleh siswa dalam kegiatan pembelajarannya dengan menetapkan sasaran pencapaian sarana dan prasarana yang meliputi: (1) 
terpenuhinya media pembelajaran yang standar; (2) terciptanya lingkungan madrasah yang aman dan nyaman serta mendukung pembelajaran; 3) tersedianya sarana pendukung pembelajaran yang standar; dan (4) tertatanya sistem informasi madrasah yang standar.

\section{SIMPULAN}

Berdasarkan hasil penelitian dan pembahasan dalam tesis ini maka dapat ditarik simpulan bahwa kepala Madrasah Tsanawiyahh Satu Atap Mikrajussibyan NW Selanglet, mengimplementasikan visi misinya dengan mendorong segenap komponen madrasah untuk bekerjasama mewujudkan visi misi. Adapun cara Kepala Madrasah mendorong segenap komponennya adalah, dengan mengarahkan semua komponen untuk memiliki budaya-budaya unggul dan islami, menjadikan visi madrasah sebagai alat untuk mengarahkan haluan dan tujuan madrasah, mewujudkan standar nasional pendidikan, memahami dan menjiwai visi misi madrasah, menjadikan misi madrasah sebagai penjabaran visi untuk mewujudkan tujuan madrasah, Mengupayakan agar misi Madrasah tetap sejalan dengan perkembangan teknologi dan informasi, menjadikan misi sebagai pendorong untuk menggali potensi, kreasi, dan inovasi yang dimiliki warga Madrasah demi terwujudnya tujuan.

Strategi yang diterapkan Kepala Madrasah dalam menjalankan proses kepemimpinannya di Madrasah Tsanawiyahh Satu Atap Mikrajussibyan NW Selanglet adalah dengan menerapkan kurikulum tingkat satuan pendidikan, mendorong upaya-upaya kreatif guru dan siswa, mengadakan penambahan jam pelajaran, memilih guru-guru yang sesuai dengan latar belakang pendidikannya, mengadakan ekstrakurikuler, menyeleksi calon input Madrasah dan membagi siswa atas tiga kelompok besar, yaitu: berkualitas tinggi, berkualitas sedang; dan berkualitas rendah dan membaginya dalam kelas heterogen, menggiatkan Unit Pengembangan Minat dan Bakat (UPMB), Memacu siswa akhir untuk menghasilkan output yang memenuhi SKL, memberdayakan guru dan karyawan, meningkatkan kesejahteraan guru dan karyawan, memberikan beasiswa study 
lanjut, melengkapi sarana dan prasarana yang kurang secara bertahap dengan skala prioritas.

\section{REFERENCE}

A,Malik Fajar, Visi Pembaruan Pendidikan Islam, Jakarta: LP3NI, 1998.

A. J. Dubrin, Leadership: Research Findings, Practices, and Skills, Boston: Houghton Mifflin Company, 2001.

Ace Suryadi, Analisis Kebijakan Pendidikan: Suatu Pengantar, Bandung: PT Remaja Rodda Karya, 1996.

Abdurrahman Mas'ud, Paradigma Pendidikan Islam, Yogyakarta: Pustaka Pelajar Offset, 2001.

Burhanuddin, Analisis Administrasi Manajemen dan Kepemimpinan Pendidikan, Jakarta: Bumi Aksara, 1994.

Baharuddin, "Kepemimpinan Kepala Sekolah dalam Era Otonomi Pendidikan", Malang: Jurnal al-Harakah, 2006 Charles J. Keating, The Leadership Book, "terj" A.M. Mangunhardjana, Kepemimpinan: Teori dan Pengembangannya, Yogyakarta: Kanisius, 1986.

Djumhur, Bimbingan dan Penyuluhan di Sekolah, Bandung: CV Ilmu, 1975.

Deddy Mulyana, Metode Penelitian Kualitatif, Bandung: PT. Rosda Karya, 2001.

E. Mulyasa, Menjadi Kepala Sekolah Profesional dalam Konteks Menyukseskan MBS dan KBK, Bandung: Remaja Rosdakarya, 2003

EM. Kaswardi, Pendidikan Nilai Memasuki Tahun 2000,Jakarta : Gramedia, 1993.

Edward Sallis, Total Quality Management In Education, "ter” Manajemen Mutu, Ahmad Ali Riyadi \& Fahrurrozi. Yogyakarta. 2008.

Gaffar. MS, Dasar-dasar Administrasi dan Supervisi Pengajaran, Jakarta: Angkasa Raya, 1992.

Gary Yulk, Leadership in Organizations, "terj"Jusuf Udaya, Kepemimipinan dalam Organisasi ,Jakarta: Prenhallindo, 1998.

G.J. Renier, Metode dan Manfaat Ilmu Sejarah Terj. Muin Umar, Yogyakarta: Pustaka pelajar, 2000.

Hendyat Soetopo, Kepemimpinan dan Supervisi Pendidikan, Jakarta: Bina Aksara, 1984..

Imam Suprayogo, Reformulasi Visi dan Misi Pendidikan Islam, Malang: STAIN Press, 1999.

Ibrahim Bafadal, Supervisi Pengajaran: Teori dan Aplikasinya dalam Membina Professional Guru, Bumi Aksara: Jakarta, 1992.

Jamal Madhi, Al Qiyadah Al-Muatsirah, "terj" Amang Syafrudin, Menjadi Pemimpin yang Efektif dan Berwibawa, Bandung: Syamil Cipta Media, 2004.

Kartini Kartono, Pengantar Ilmu Mendidik Teoritis, Bandung: Mandar Maju, 1992. 
Syafaruddin, Manajemen Mutu Terpadu dalam Pendidikan: Konsep, Strategi dan Aplikasi, Jakarta: Grasindo, 2002.

Lexy J. Moleong, Metode Penelitian Kualitatif: Edisi Revisi, Bandung: PT Remaja Rosdakarya, 2006.

M. Jusup Hanafiah, dkk, Pengelolaan Mutu Total Pendidikan Tinggi, Badan Kerjasama Perguruan Tinggi Negeri, 1994.

Muhaimin, Paradigma Pendidikan Islam: Upaya Mengefektifkan Pendidikan Agama Islam di Sekolah, Bandung: Remaja Rosdakarya, 2004.

Mike PEGG, "Positive Leadership", diterjemahkan Arif Suyoko, Kepemimpinan Positif (Jakarta: Pustaka Binaman Pressindo, 1994), 6.

M. Ngalim Purwanto, Administrasi Pendidikan, Jakarta: Mutiara Sumber Widya, 1991.

Moleong, Metode Penelitian Kualitatif, Bandung: Remaja Rosdakarya, 1991.

Nana Syaodih Sukmadinata. Dkk, Pengendalian Mutu Pendidikan Sekolah menengah: Konsep, Prinsip, dan Instrumen, Bandung: Refika Aditama, 2006.

Noeng Muhadjir, Metodologi Penelitian Kualitatif, Yogyakarta: Ekesarasin, 1988.

P. G. Northouse, Leadership: Theory and Practice, New Delhi: Response Book, 2003.

Suharsimi Arikunto, Prosedur Penelitian: Suatu Pendekatan Praktek, Jakarta: PT. Rineka Cipta, 2010.

Sugiyono, Metode Penelitian Kuantitatif Kualitatif dan R\&D, Bandung: Alfabeta, 2006.

Sugeng Listyo Prabowo, Manajemen Pengembangan Mutu Sekolah/Madrasah, Malang: UIN Malang Press, 2008.

Sudarwan. Menjadi Komunitas Pembelajar, Jakarta: Bumi Aksara, 2003.

Wahjosumidjo, Kepemimpinan Kepala Sekolah, PT. Raja Grafindo Persada, Jakarta, $\mathrm{t}$.

Wijono, Administrasi Dan Supervisi Pendidikan, Jakarta: Departeman Pendidikan Dan Kebudayaan, 1989.

Zakiah Daradjat, Ilmu Pendidikan Islam, Jakarta: Bumi Aksara, 1996. 